\title{
L-051＼cjkstart企業のホワイトカラー労働者が職場に抱く感情と精神的健康につ いての研究〜精神科受診歴のある群とない群の比較〜
}

講演者 : 山田一子 (横浜国立大学大学院教育相談・支援総合センター) 司会者: 井上 果子 (横浜国立大学)

バブル崩壊以降，経済や社会環境の変容に伴い，企業の職場環境も変化した。企業では，仕事の質の 追及, 時間外労働の増加が生じ, 労働者の業務負荷は増大している。加えて, 非正規雇用の労働者数も 拡大し, 労働者間格差も指摘される中で, 労働者のうつ病や精神的健康の低下が社会的問題とされ, 有 効な対応策が求められている。また近年, 職場における労働者の感情と精神的健康に関連する研究も進 んでいるが, 事例研究が多く, 実証的研究が必要と考えられた。

本小講演では, 企業の職場の中で労働者に生じる感情に着目し, 働く労働者や, うつ病を発症し医療 機関を受診した労働者を対象に調查を行った研究を紹介する。研究では, 労働者が職場に向ける感情の 抽出を行い, 労働者の職場感情とパーソナリティ傾向や精神的健康を測定する尺度を用いて質問紙調查 を実施した。得られたデー夕を分析した結果に基づいて労働者の職場適応や精神的健康について考察を 行う。

第 3 日 9 月22日 (金) $\quad 13: 40 \sim 14: 30$

$4 \mathrm{~F} /$ スタジオ 1

\section{L-052＼cjkstart直観像の生起メカニズムに関する研究：直観像保持者の特徵とは 何か}

\author{
講演者：名畑（新原）理津子（北海道大学） \\ 司会者：小川 健二 (北海道大学)
}

直観像とは，過去に観察した視覚刺激が外部空間に定位され，文字通り目に見えると感じられる心的 視覚イメージの一種である。直観像は心理学研究の黎明期から多くの心理学者の関心を集めてきた現象 であるものの, 未だその正体は明らかになっていない。本研究は, 心理学の古い研究テーマの一つであ る直観像に再び焦点を当て, その生起メカニズムの一端の解明を試みた。本小講演では, 直観像の生起 メカニズムの探求に際して行われた, 直観像保持者の特性に関する行動実験や MRI 実験について紹介す る。そして, これらの実験結果から示唆される, 直観像生起メカニズムの仮説的モデルについて論じる。 また, 直観像のような極めて主観的な意識体験を科学的研究の组上に載せるために何が必要であるかに ついて考察する。 